\title{
A Mixed-Method Examination of Adopting Focus-on-Form TBLT for Children's English Vocabulary Learning
}

\author{
Zih-ying $\mathrm{Lu}^{1} \&$ Sa-hui Fan ${ }^{1}$ \\ ${ }^{1}$ English Dept., National Taichung University of Education, Taiwan \\ Correspondence: Sa-hui Fan, English Dept., National Taichung University of Education, Taiwan.
}

Received: December 31, 2020

Accepted: January 28, 2021

Online Published: January 29, 2021

doi: $10.5539 /$ elt.v14n2p37

URL: https://doi.org/10.5539/elt.v14n2p37

\begin{abstract}
This study investigated the influence of focus-on-form task-based language teaching (TBLT) on Taiwanese children's English vocabulary acquisition and retention. Focus-on-form TBLT here refers to instruction in which the teacher and students interact, negotiate, and respond to each other on the subject of a second language (L2) vocabulary. The participants $(\mathrm{N}=71)$ were all enrolled in the third grade of a central Taiwan elementary school. The experimental group $(\mathrm{N}=42)$ received TBLT lessons with a focus on form. In contrast, the control group ( $\mathrm{N}$ = 29) received more conventional lessons based on the presentation-practice-production (PPP) model. Quantitative data were collected from three vocabulary tests. Qualitative data were gleaned from the teacher/researcher's journal logs. Although the statistical comparisons showed no significant differences between the two groups in the three VKS tests, the qualitative data suggest that students in the two groups responded differently in terms of their in-class interaction and personal involvement. It seems that interaction and output production induced in the experimental group possibly facilitated the comprehension and acquisition of L2 vocabulary. The study also provides pedagogical implications for implementing TBLT with a focus on form to increase the retention of L2 vocabulary.
\end{abstract}

Keywords: task-based language teaching, vocabulary acquisition, vocabulary retention, focus on form, L2 for children

\section{Introduction}

Over the past few decades, English has gradually become a lingua franca. To meet the demands of globalization (Chen, 2013; Chen \& Huang, 2017; Chern, 2002), the Taiwanese government has initiated two major reforms of English education. They were the Nine-Year Joint Curriculum Plan initiated in 2001 and Twelve-Year Basic Education in 2019; both were administered in the hope of encouraging students to become lifelong learners. The English curriculum guidelines from the Nine-Year Joint Curriculum Plan focus on the communicative approach; for primary school, it highlights the development of students' listening and speaking abilities (Ministry of Education, 2000). Also, the concept of core competencies in the Twelve-Year Basic Education emphasizes competency education and lifelong learning (Ministry of Education, 2014).

Despite governmental efforts to redirect school teaching toward real-life skills and experiences, the current dominant language teaching practices in Taiwan seem to contradict the vision of national curriculum guidelines. These practices highlight form instruction (Lin \& $\mathrm{Wu}, 2012$ ) developed from the presentation-practice-production (PPP) model. According to Anderson (2016), this model has been a popular and long-lasting teaching technique in the mainstream of EFL (English as a foreign language) classrooms. In spite of this, the PPP model has been criticized for its overemphasis on sequential learning, discrete linguistic items, teacher-centeredness, and restricted communicative competence development (Lewis, 1996; Skehan, 1998; Willis \& Willis, 1996).

The criticism of PPP has led to the emergence of task-based language teaching (TBLT; Lewis, 1996; Skehan, 1998; Willis \& Willis, 1996). The implementation of TBLT has encountered difficulties with respect to the learning context in Taiwan, as well as in many other Asian countries. However, according to Lin and Wu (2012), there is a positive attitude towards TBLT among Taiwanese English teachers. Also, their finding echoes other studies in East Asian contexts (Carless, 2004, 2007; Harris, 2018). English teachers in Asia generally seem to hold a positive attitude toward TBLT. Nonetheless, researchers in Asia have also found that contextual and cultural constraints have hindered the implementation of TBLT. For example, Lin and Wu (2012) interviewed 
teachers who suggested that TBLT may not cater to the test-driven context in Taiwan; in addition, they also expressed the need to follow a rigid teaching syllabus in a limited amount of time. Hence, Carless (2007) proposed an adaptation of TBLT for Asian countries in which the tasks are combined with examination requirements and consider other contextual constraints.

TBLT is supported by the philosophy of the Twelve-year Basic Education curriculum guidelines in Taiwan, but with the educational constraints in Asian countries as exemplified above, unsuccessful outcomes may be anticipated. More empirical studies on the implementation of TBLT in an Asian context should be carried out to provide insights into how to put effective TBLT instructions into practice in Asian countries. This study set out to explore the application of TBLT with a focus on form and its influence on children's vocabulary acquisition and retention in Taiwan. The research questions are listed below:

1. Does focus-on-form TBLT enhance children's L2 vocabulary acquisition and retention in Taiwan?

2. How does focus-on-form TBLT influence the L2 vocabulary acquisition process of Taiwanese children?

\section{Literature Review}

The development of task-based language teaching (TBLT) is based on the rationale of communicative language teaching (CLT) and the interaction hypothesis (Ellis, 2009). The main ideas of TBLT are learner-centered, meaning-based communicative tasks (Ellis, 2003). Long's (1998) interaction hypothesis suggests that interaction can help L2 development because it encourages the negotiation of meaning and thus makes input salient and noticed. During interactive tasks, "the linguistic units are rephrased, repeated and reorganized to aid comprehension" (Mackey, 1999, p. 558). Many studies have focused on exploring the effects of interaction on different aspects of L2 learning and have found positive outcomes (Ellis, Tanaka, \& Yamazaki, 1994; Gass, 1997; Mackey, 1999; Pica, 1992). Ellis and He (1999) also suggest that interaction involving learners to use or negotiate new words in conversation appears to create a better environment for vocabulary acquisition. Negotiations of meaning produced during interactive tasks may enhance L2 development.

\section{Definition of a "Task"}

The notion of a task is a crucial foundation in TBLT. Long (1985) frames the approach in terms of tasks in a broad sense: "a task is a piece of work undertaken for oneself or for others, freely or for some reward. Thus, examples of tasks include painting a fence, dressing a child..." (p. 89). In other words, a task refers to what people do in everyday life, even if tasks do not necessarily involve the use of language. Because learning contexts have been transformed from the "real world" to man-made classrooms, Skehan (1998, p. 95) illustrated specific characteristics of a task as "an activity in which: meaning is primary; there is some communication problem to solve; there is some sort of relationship to comparable real-world activities; task completion has some priority; the assessment of the task is in terms of outcome" (p. 95). Both Long (1985) and Skehan (1998) affirm that a task should be related to real life and represent a meaningful activity.

However, a real-world task might be too difficult for learners to carry out due to limited language proficiency. As a result, tasks that can be pedagogically applied and serve as a bridge between the real world and the L2 classroom have been put forth. Ellis's (2003) proposed definition posits that a task is meaning-focused but should also be open to focusing on linguistic forms as well.

In addition, Nunan (2004) offers a definition of tasks from a pedagogical perspective. Nunan's definition emphasizes both the pedagogical application of a task in L2 classrooms and meaningful communication. In addition to the many definitions mentioned above, Bygate et al. (2001) suggest a broader definition: "A task is an activity which requires learners to use language, with emphasis on meaning, to attain an objective" (p. 11). The following features of tasks were described by Ellis (2009):

1. The primary focus should be on "meaning."

2. There should be some kind of "gap."

3. Learners should largely have to rely on their own resources (linguistic and non-linguistic) in order to complete the activity.

4. There is a clearly defined outcome other than the use of language (p. 223).

As for the sequence of a task activity, Willis and Willis (1996) propose three pedagogical steps for TBLT: pre-task, task cycle and language focus. These are described as follows: 
1. The pre-task stage functions as preparation for the task. It consists of introducing the topic, providing input, and activating the learners' motivation and prior knowledge.

2. In the task cycle, learners do the task and plan for the presentation of their work at the same time, and finally, report to the class on their work.

3. The final stage, language focus, is for analyzing and practicing the target linguistic features that were used during the task.

\section{Criticisms of TBLT}

Despite the support that TBLT has gained, it has been the subject of some doubts as well. Some have indicated that TBLT has no grammar syllabus since it emphasizes natural language use (Sheen, 2003; Swan, 2005). Swan (2005) suggests that TBLT overlooks the acquisition of vocabulary and phonological awareness due to its inclination towards incidental learning. Ellis (2009) responded to these questions by proposing focus-on-form TBLT that caters to phonology and vocabulary. Others (Lyster, 1998; Swain, 1985) have criticized TBLT for simply immersing L2 learners in a pure meaning-focused context, which they suggest could not lead to high levels of language competence development. With this in mind, several researchers (Doughty \& Williams, 1998; Ellis, 2003; Long, 1998) agree that attention to form can compensate for the weaknesses of TBLT. The inclusion of focus-on-form TBLT in particular is seen as addressing some of these weaknesses.

\section{Focus-on-Form TBLT}

Focus-on-form was first proposed by Long in 1985, and its details and features continue to receive elaboration. As defined by Long, focus-on-form overtly TBLT draws students' attention to linguistic elements as they arise incidentally in lessons whose overriding focus is on meaning or communication" (p. 45). Long further illustrated that its purpose of a "temporary shift" was to allocate the learners' attention to the linguistic form when the occasion was triggered by communication problems. When learners encounter difficulties in comprehending or communicating (learner-noticed problems), then the problem will be addressed overtly, thus leading to the continued process of the negotiation of meaning (Long, 1998).

As the evolution of TBLT has continued, Long updated his definition in 2015: "focus on form involves reactive use of a wide variety of pedagogic procedures to draw learners' attention to linguistic problems in context, as they arise during communication in TBLT" (p. 317). The core idea of focus-on-form did not alter; that is, the attention is still drawn to the linguistic form when learners are communicating. Nonetheless, focus-on-form can be seen as "procedures" rather than an "approach" that can be incorporated into a communicative curriculum, such as TBLT.

Ellis (2016) also proposed a pedagogical definition of focus-on-form TBLT as "a set of techniques deployed in a communicative context by the teacher and/or the students to draw attention implicitly or explicitly...for the learners" (p. 7). Moreover, focus-on-form can be pre-planned to address a specific linguistic element in a meaning-focused lesson. In addition, Ellis, Basturkmen, and Loewen (2001) suggest that focus-on-form TBLT can be directed at phonology, vocabulary, grammar, or discourse. Ellis (2016) continues to elaborate that "form can refer to lexical (both phonological and orthographic), grammatical, and pragmalinguistic features" (p. 4). In other words, "form" can be the meaning of a word form.

\section{Focus-on-Form TBLT and Vocabulary Tasks}

According to Doughty and Williams (1998), focus-on-form can facilitate lexical acquisition along with the help of interaction. Vocabulary learning involves three main processes: the acquisition of forms, meanings, and the proper usage of words in certain contexts (Kit, 2003). With intervention (focus-on-form) during tasks, Skehan (1998) argued that focus-on-form vocabulary tasks strengthen the relationship between form and the meaning of words.

Ellis (2001) investigated focus-on-form TBLT in an EFL classroom and found that there were 159 times that focus-on-form communications involved vocabulary, and successful uptake was up to $67.5 \%$. In another study, Ellis et al. (2001) found that $60 \%$ of focus-on-form communications initiated by the teacher addressed vocabulary, and an even higher rate $(66 \%)$ occurred in student-initiated focus-on-form communications. The two studies showed that focus-on-form TBLT was largely allocated to vocabulary. In line with Ellis' studies, Alcón (2007) gives evidence that teachers' focus-on-form TBLT is beneficial to students' vocabulary learning because it enhances learners' noticing and results in improving their knowledge and use of vocabulary. 


\section{Vocabulary Acquisition}

A study by de la Fuente (2006) investigated the effects of three types of vocabulary lessons (one PPP model, one focus-on-form TBLT, and TBLT) on the acquisition of Spanish words. The results showed that the types of approach had no particular impact on immediate vocabulary retrieval but did on long-term retrieval. Task-based lessons especially appeared to be more effective than PPP lessons. Furthermore, it suggests that focus-on-form TBLT was more effective on long-term retrieval than the one without a focus on form. This study showed positive evidence that the incorporation of TBLT and focus-on-form plays an important role in L2 vocabulary learning.

Shintani (2013) investigated the effect of TBLT and PPP lessons on Japanese children's English vocabulary acquisition. The results showed that both types of approach were effective for the acquisition of nouns, but the TBLT group performed better on the acquisition of adjectives. Shintani indicated that the acquisition of adjectives happened in order to achieve the negotiation of meaning in the TBLT group, whereas the PPP lesson group was not provided with this kind of opportunity. That is, tasks with focus-on-form instruction create contexts for the acquisition of vocabulary, especially for younger learners.

In Taiwan, Yang, Haggard, and Chiung (2008) investigated the effects of focus-on-form on college students ' learning of possessive pronouns. In their study, focus-on-form referred to instruction that emphasized linguistic elements and discrete grammar rules. They showed that the experimental group that received input enhancement significantly outperformed the control group. Thus, the study concluded that input enhancement that draws the learners' attention to the target form could facilitate the learners' acquisition of target forms.

\section{Presentation-Practice-Production (PPP) Model}

There are various descriptions of the PPP model (Criado, 2013; Harmer, 1998; Skehan, 1998; Willis \& Willis, 1996); thus, a broad definition is presented as follows:

1. The presentation stage is when the teacher presents pre-selected target language items, involving the students in an explicit way of learning. The target items are presented first, and explanations of the construction of the target linguistic features are then offered.

2. The practice stage provides controlled practice (e.g., drills and fixed question-answer activities) that aim at the accuracy of the target form.

3. The production stage gives learners opportunities to use the target language through activities, such as role-plays and information gaps, in order to induce free language output.

Based on the procedures described above, the language is learned sequentially, and learners can concentrate on the target linguistic elements. After proper practice, learners are expected to produce accurate and fluent language output. The stages consist of a reasonable learning process that leads learners to successful acquisition. In addition, the model is often carried out in teacher-led instruction (Criado, 2013). Hence, due to the learning context (a teacher-centered orientation), the PPP model has been widely adopted by teachers in Asian EFL learning classrooms (Adams \& Newton, 2009; Carless, 2007; Ji, 2017; Lin \& Wu, 2012; Littlewood, 2007).

Criticisms of the PPP model have also been made. One criticism is that the sequence of PPP seems to be unrealistic since it goes against the natural language acquisition system. According to Willis and Willis (1996), free production is often not successful after the sequence of PPP since learners may not be ready to produce output. Moreover, discrete-item learning may give learners a false assumption that language could be accumulated through isolated items with controlled activities, thus resulting in deficient communication in real life. In addition, the teacher-centered orientation may reduce learners' active perceptions regarding the language since the teacher leads the process of teaching.

With the empirical studies of both focus-on-form TBLT and the PPP model presented above, it seems necessary for Asian EFL teachers to understand if focus-on-from TBLT is more effective than the popular PPP model for young learners' vocabulary acquisition. However, there are scarce studies that have been conducted in the context of Asia regarding this question.

\section{Research Methods}

This study mainly adopted a quasi-experimental design supplemented by qualitative data elicited from the classes. The experimental group received focus-on-form TBLT lessons. In contrast, the control group received lessons based on the PPP model. 


\section{Context and Participants}

A total of 71 third-graders, aged 10 to 11, in a public elementary school located in Central Taiwan and known for its English-featured curriculum, participated in this classroom-based quasi-experimental study. They were randomly assigned by the school into three classes (designated here as Class A, B, and C) that were taught by the same English teacher (who is also the first author of this study). The experimental group included two intact classes (Classes A and B) with 20 boys and 22 girls; the control group was another intact class (Class C) with 15 boys and 14 girls (see Table 1). All the students had been receiving three 40-minute English classes per week since the first grade. About $95 \%$ of them had also joined private English programs. However, the students' English proficiencies were mixed according to the results of previous exams and the teacher/researcher's observations.

Table 1. Distribution of the Students in the Classes

\begin{tabular}{lccc}
\hline \multicolumn{1}{c}{ Groups } & \multicolumn{2}{c}{ The experimental group } \\
& Class A & The control group \\
& & Class B & $(\mathrm{N}=29)$ \\
\hline Three intact classes & Male: 12 & Male: 8 & Class C \\
Students & Female: 11 & Female: 11 & Male: 15 \\
& & & Female: 14 \\
Total & & $\mathrm{N}=42$ & $\mathrm{~N}=29$ \\
\hline
\end{tabular}

\section{Instructional Procedure}

Two English textbooks were used in this school. One textbook was designed by a textbook publisher based on the educational accreditation set by the Taiwan Ministry of Education with eight target words and two target sentences in each unit. The other textbook contained school-compiled supplementary materials and was an extension of the first one. The target vocabulary of the experimental tasks was drawn from the supplementary textbook (see Appendix A).

Learners in the two groups worked on the same topic of "feelings" during the same period of time. The experimental duration was two weeks with six 40-minute English classes; the experimental group received focus-on-form TBLT, while the control group received an explicit vocabulary learning lesson based on the PPP model. The two groups went through different instructional procedures because of the various requirements of compiling the two teaching approaches. The common time frame is illustrated in Table 2.

Table 2. Treatment Procedure

\begin{tabular}{llll}
\hline September & October & November & February \\
\hline Fall Semester & $\begin{array}{l}\text { The study began with } \\
\text { Lesson 2 of the }\end{array}$ & $\begin{array}{l}\text { Test 2 was administered } \\
\text { two weeks after Test 1. }\end{array}$ & $\begin{array}{l}\text { Spring Semester } \\
\text { This was a preparation } 3 \text { was } \\
\text { and warm-up period for } \\
\text { the students. }\end{array}$ \\
& $\begin{array}{l}\text { textbook in six periods } \\
\text { of class. } \\
\text { Test 1 was administered } \\
\text { after the treatment. }\end{array}$ & & \\
& & & \\
& & &
\end{tabular}

The Experimental Group. Students in the experimental group carried out two tasks embedded in the teacher's focus-on-form TBLT. It included six periods of class and two tasks that were carried out (see Table 3). During the meaning-focused lessons, the focus-on-form TBLT procedures occurred naturally when the teacher and students interacted, discussed, or negotiated. The teacher corrected linguistic mistakes made by the students and provided feedback when questions were raised. 
Table 3. Instructional Procedure in the Experimental Group

\section{Period 1}

- Input-based lesson

- $\quad$ Task 1: "How do you

feel?" comic worksheet

\section{Period 4}

- $\quad$ Task 2 finished and shared with the teacher and classmates

\section{Period 2}

- $\quad$ Task 1: "How do you feel?" comic worksheet

- $\quad$ Task 1 finished and shared with the teacher and classmates

\section{Period 5}

- Workbook practice

\section{Period 3}

- Task 2: I feel when (How does he/she feel?)

\section{Period 6}

- $\quad$ Test 1 administration

In Periods 1 and 2 (see Table 4), the students carried out a task that involved using eight target words and the sentences "How do you feel?" and "I feel _.." It started with an input-based lesson that introduced the target words as preparatory focus-on-form instruction along with the sentences in the textbook. The purpose of this lesson was to build up students' basic familiarity with the target words and functional sentences that could be used in the task. Task 1 was inclined to the real-life characteristics of TBLT.

In Periods 3 and 4 (see Table 5), the task required the students to first write down their feelings about three situations (typhoon, test, and earthquake). The sentence patterns were: "When there is a ___, I feel __.." and "How do you feel when there is a _ ?" Students created their sentences by combining actual experiences and target words to express their feelings. After completing the sentences, the students played the roles of interviewers and interviewees to investigate each other's thoughts regarding different situations. The design of Task 2 induced an exchange of information using the target language. That is, the task required the students to use the sentences and target words and keep a record of the answers in the textbook. After the interviews, the students reported their thoughts. Another question, "How does he/she feel?" was brought up when the teacher asked about other students. The students were mainly focused on the meaning when the teacher asked the question. The teacher then turned the students' attention to the grammar in the answer, which required the addition of an "s" on the end of the verb, and explained the cause.

At this point, each student was acquainted with the target words, whether the input was from himself/herself, others, or the teacher. In Period 5, the teacher reviewed the target words and let the students finish their workbook practice, which also involved the target words. In Period 6, the first vocabulary test was administered.

Table 4. Task 1 Design in the Experimental Group

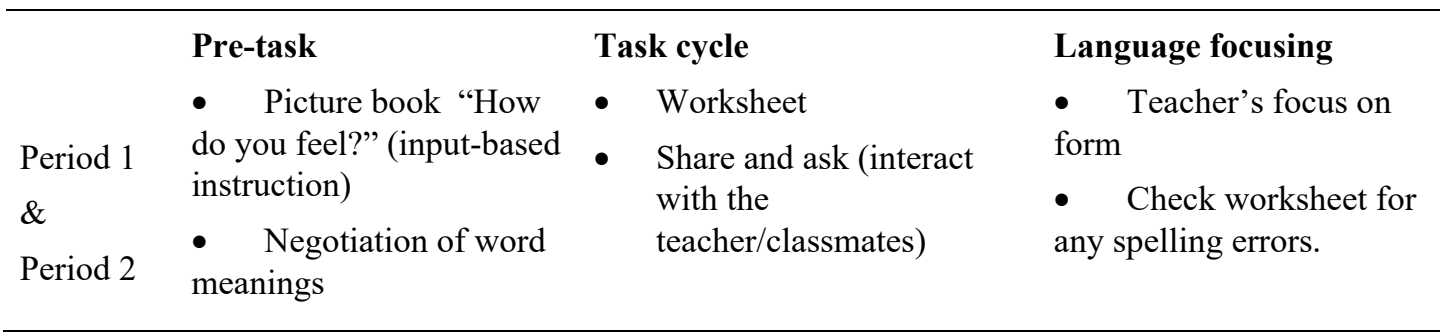

Table 5 Task 2 Design in the Experimental Group

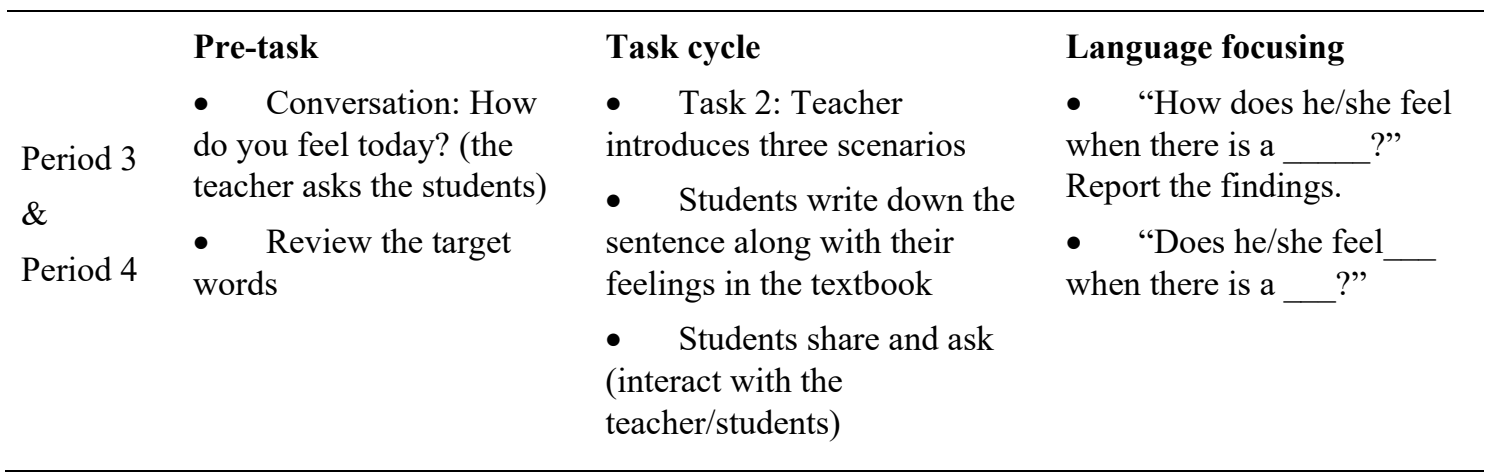


The Control Group. The control group received lessons using the PPP model (see Table 6). It consisted of five periods and three activities (see Table 6).

Table 6. Instructional Procedure in the Control Group

\section{Period 1}

- $\quad P 1$ : Teacher explains the meaning and forms of the target words

- $\quad P 2$ : Word recognition exercise (flashcards)

- $\quad$ P3: Activity 1 (an acting and guessing game)

\section{Period 4}

- Workbook practice

\section{Period 2}

- P1: Teacher presents the sentences: "How does he/she feel?" and "He/she feels

- $\quad$ P2: Sentence exercise (questions and answers)

- $\quad$ P3: Activity 2 (read and write exercise)

\section{Period 3}

- $\quad P 1$ : Teacher presents the sentences: "Does he/she feel_?" and "Yes, he/she does./No, he/she doesn't."

- $\quad$ P2: Sentence drills (flashcards)

- P3: Activity 3 (a guessing game: "Does he/she feel ?")

\section{Period 5}

- $\quad$ Test 1 administration

The control group received PPP model lessons carried out in a sequence of three stages (presentation, practice, and production). Students were involved in focused activities, and the target words were taught through first language translation. The teacher used flashcards to familiarize students with the meanings and forms of the target words. Throughout the practice stage, the target words were rehearsed repeatedly in pairs or individually. The presentation stage was carried out using a direct, decontextualized one-way activity. The input was "pre-modified" since it was aimed at students' comprehension. In this case, the negotiation of meaning was not needed.

\section{Instruments}

Quantitative data were collected from three vocabulary tests: a post-test, a delayed test, and a second delayed test. Qualitative data were gleaned from the teacher/researcher's journal logs. The details are presented below.

Vocabulary Knowledge Scale (VKS). In this study, the Vocabulary Knowledge Scale (VKS) developed by Wesche and Paribakht (1996) was adapted for the three tests to measure the learners' vocabulary acquisition and retention. It employed a five-point scale that combined a self-report and progressive accounts of performance to reflect the learners' knowledge of particular words in written form. This instrument was chosen to measure vocabulary acquisition for this study because of its conventional evaluation of memorization and recognition. Based on Paribakht and Wesche (1997), the scale ratings ranged from 1 to 5 and aimed to examine the learners' familiarity with word forms and meanings (see Figure 1). The participants responded by using the scales to categorize and score their responses. The scales were presented as follows:

I. I don't remember having previously seen this word.

II. I have previously seen this word, but I don't know what it means.

III. I have previously seen this word, and I think it means [synonym or translation]

IV. I know this word it means . [synonym or translation]

IV. I can use this word in a sentence: [write a sentence]

This instrument contained both receptive and productive vocabulary development, so it elicited learners' perceived knowledge of the words in Categories I and II and a productive response in Categories III, IV, and V. 


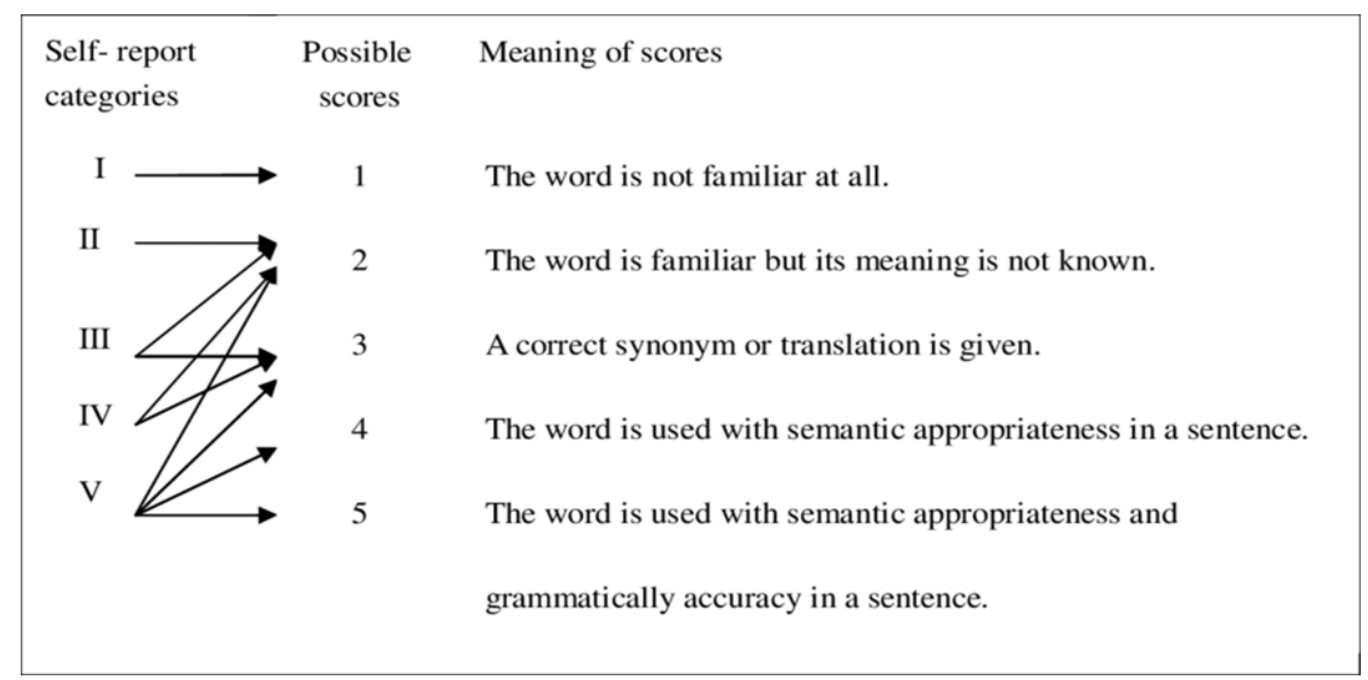

Figure 1.VKS Scoring Categories

In other words, the VKS provided measurements that could verify that the learners demonstrated knowledge in each scoring point: 1 (completely unfamiliar), 2 (familiar but don't know the meaning), 3 (a correct translation/synonym was given), 4 (the word was used correctly in a sentence but with grammatical errors), and 5 (the word was used correctly in a sentence with appropriate grammar) (see Figure 1). Learners marked their understanding of the target words with regard to the five scale levels. Each level represented a progressive step in target word retention. A sample of the Chinese version VKS is provided (see Appendix B).

Teacher/Researcher's Journal Logs. In order to provide multi-leveled insights in the two approaches, class journal logs were kept by the researcher/teacher. The teacher wrote down observed episodes of action after every English class. Conversation analysis (Hutchby \& Wooffitt, 2008) was adopted to identify and interpret the interactions, utterances, and inquiries among the teacher and students.

\section{Test Procedure}

The following presents the VKS test procedure (see Table 7). Three VKS tests were administered to the experiment group. The teacher first explained how to complete the test and confirmed to the students that the results would not affect their school grades.

Table 7. VKS Test Procedure

\begin{tabular}{|c|c|c|}
\hline Test 1 & Test 2 & Test 3 \\
\hline $\begin{array}{l}\text { Fall Semester, Week } 3 \\
\text { - Time: Period } 6 \text { in the } \\
\text { experimental group and Period } 5 \\
\text { in the control group } \\
\text { - Duration: } 20 \text { minutes } \\
\text { - Eight target words with two } \\
\text { other words ("lonely" and } \\
\text { "feel") }\end{array}$ & $\begin{array}{l}\text { Fall Semester, Week } \mathbf{5} \\
\text { - } \quad \text { Time: Two weeks after } \\
\text { Test } 1 \\
\text { - } \quad \text { Duration: } 20 \text { minutes } \\
\text { - } \quad \text { Ten words are reordered }\end{array}$ & $\begin{array}{l}\text { Spring Semester } \\
\text { - } \quad \text { Time: Three months after } \\
\text { Test } 2 \\
\text { - } \quad \text { Duration: } 20 \text { minutes } \\
\text { - } \quad \text { Ten words are reordered }\end{array}$ \\
\hline
\end{tabular}

\section{Data Analysis}

The quantitative data were collected through three VKS results. The data collected through the VKS tests were subjected to $t$-tests in an attempt to find differences between the two groups. In addition, the teacher/researcher's journal logs were kept and examined qualitatively using conversation analysis (Hutchby \& Wooffitt, 2008). Conversation analysis has previously been adopted as a tool for qualitatively examining EFL classroom interaction in the study of second language acquisition. It aided in identifying the different dynamics and acquisition processes that arose in the different instructional environments between the two groups. The researcher re-read and reflected on the class observations and the students' interactions in the two groups; during the qualitative data analysis, specific categories emerged. 


\section{Results}

The results are separated into quantitative and qualitative findings. Although the statistical comparisons showed no significant differences between the two groups in the three administrations of VKS tests, the qualitative data suggest that students in the two groups responded differently in regards to in-class interactions and personal involvement.

\subsection{Quantitative Data: VKS Test Results}

For the VKS tests, the students were required to report their level of vocabulary understanding or/and write down Chinese translations or English synonyms and sentences of the target words. There were eight target words and two other words (that were excluded from scoring) included in the test. The various Chinese translations from the students' answers are listed in Appendix C.

As illustrated in Table 8 , the $t$-test results showed that the difference between the two groups for Test 1 was not significant $(t=-0.639, p=.525)$, nor was it significant for Test $2(t=-.029, p=.997)$ or Test $3(t=.315, p$ $=.754$ ), an alpha level of .05 was used for all the tests (see Table 8).

Table 8. Test Results

\begin{tabular}{lcccccc}
\hline Groups & \multicolumn{2}{c}{ Test 1 } & \multicolumn{2}{c}{ Test 2 } & \multicolumn{2}{c}{ Test 3 } \\
\cline { 2 - 7 } & Mean & SD & Mean & SD & Mean & SD \\
\hline Experimental $(\mathrm{N}=42)$ & 27.55 & 9.037 & 27.79 & 8.736 & 23.48 & 8.309 \\
Control $(\mathrm{N}=26)$ & 28.96 & 8.586 & 27.85 & 7.708 & 22.85 & 7.535 \\
$p$-values & 0.525 & & 0.997 & & 0.754 &
\end{tabular}

However, if we compare the three VKS results, we can see that the control group dropped more steeply than the experimental group. To illustrate this point, Figure 2 demonstrates the overall score mean changes for the two groups in the three VKS tests. The line graph ranges from a maximum of 30 to a minimum of 20 . In Test 1 , the control group (28.96) performed slightly better than the experimental group (27.55). In Test 2, the control group (27.85) dropped down noticeably, while the experimental group (27.79) remained at about the same rate. In Test 3 , both groups dropped; the experimental group (23.48) yielded a more moderate result than the control group (22.85). 


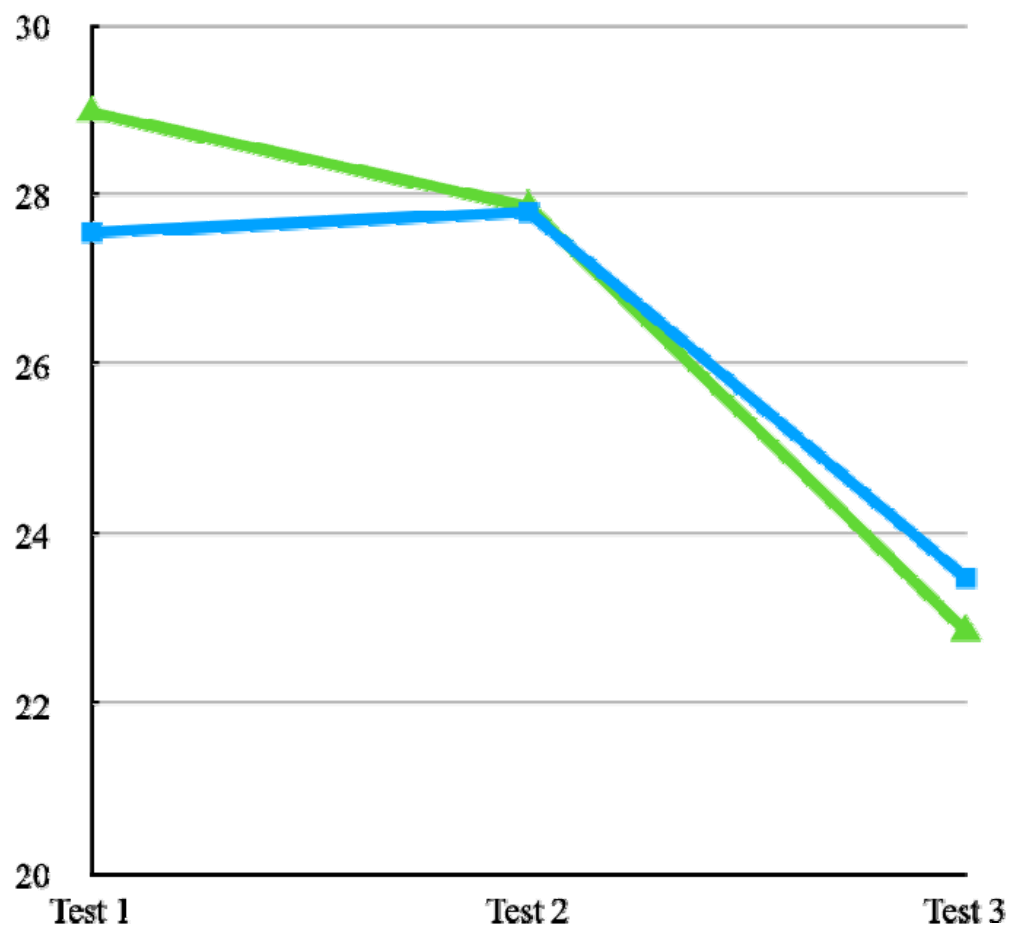

Figure 2. Comparison of Fluctuations of the Two Groups

\section{Fluctuations of Scores and Word Retention}

To further explore vocabulary retention over time, the students' original scores and word retention rates were analyzed. In Tables 9 and 10, the nature of the score changes of both groups were compared.

Table 9. Score Change of the Experimental Group

\begin{tabular}{lcc}
\hline Score Change & \multicolumn{2}{c}{ Experimental group $(\mathrm{N}=42)(100 \%)$} \\
\hline Tests & T1 to T2 & T2 to T3 \\
Improve & $21(50 \%)$ & $8(19 \%)$ \\
Remain & $2(4.8 \%)$ & $7(17 \%)$ \\
Decrease & $19(48 \%)$ & $27(64 \%)$ \\
Total & $42(100 \%)$ & $42(100 \%)$
\end{tabular}

As shown in Table 9, 19 students (approx. 48\%) in the experimental group showed decreasing scores from T1 to T2, but 27 (approx. 64\%) showed declining scores from T2 to T3. In contrast, as shown in Table 10, 14 students (approx. 53\%) in the control group showed decreasing scores from T1 to T2, and 19 (approx. 73\%) showed declining scores from T2 to T3. In addition, approximately 7 (approx.17\%) of the students in the experimental group retained the same performance in Test 3, whereas only 2 (approx. 8\%) of the students in the control group did. 
Table 10. Score Change of the Control Group

\begin{tabular}{|c|c|c|}
\hline Score Change & \multicolumn{2}{|c|}{ Control group $(N=29)(100 \%)$} \\
\hline Tests & $\mathrm{T} 1$ to $\mathrm{T} 2$ & $\mathrm{~T} 2$ to $\mathrm{T} 3$ \\
\hline Improve & $7(26 \%)$ & $5(19 \%)$ \\
\hline Remain & $5(19 \%)$ & $2(8 \%)$ \\
\hline Decrease & $14(53 \%)$ & $19(73 \%)$ \\
\hline Total & $26(100 \%)$ & $26(100 \%)$ \\
\hline
\end{tabular}

For greater clarity, Figure 3 demonstrates the comparison between the two groups from T1 to T2. It shows fewer decreasing numbers of students and higher numbers of those that remained the same (see Figure 4). It may be argued that students in the experimental group seemed to have had a delayed effect on vocabulary acquisition. One possible explanation for the difference found between the two groups might be, as Gass and Varonis (1994) point out, that "the absence of short-term effects does not exclude the possibility of long-term effects when the learner has had sufficient time to process and incorporate the feedback" (p. 286).

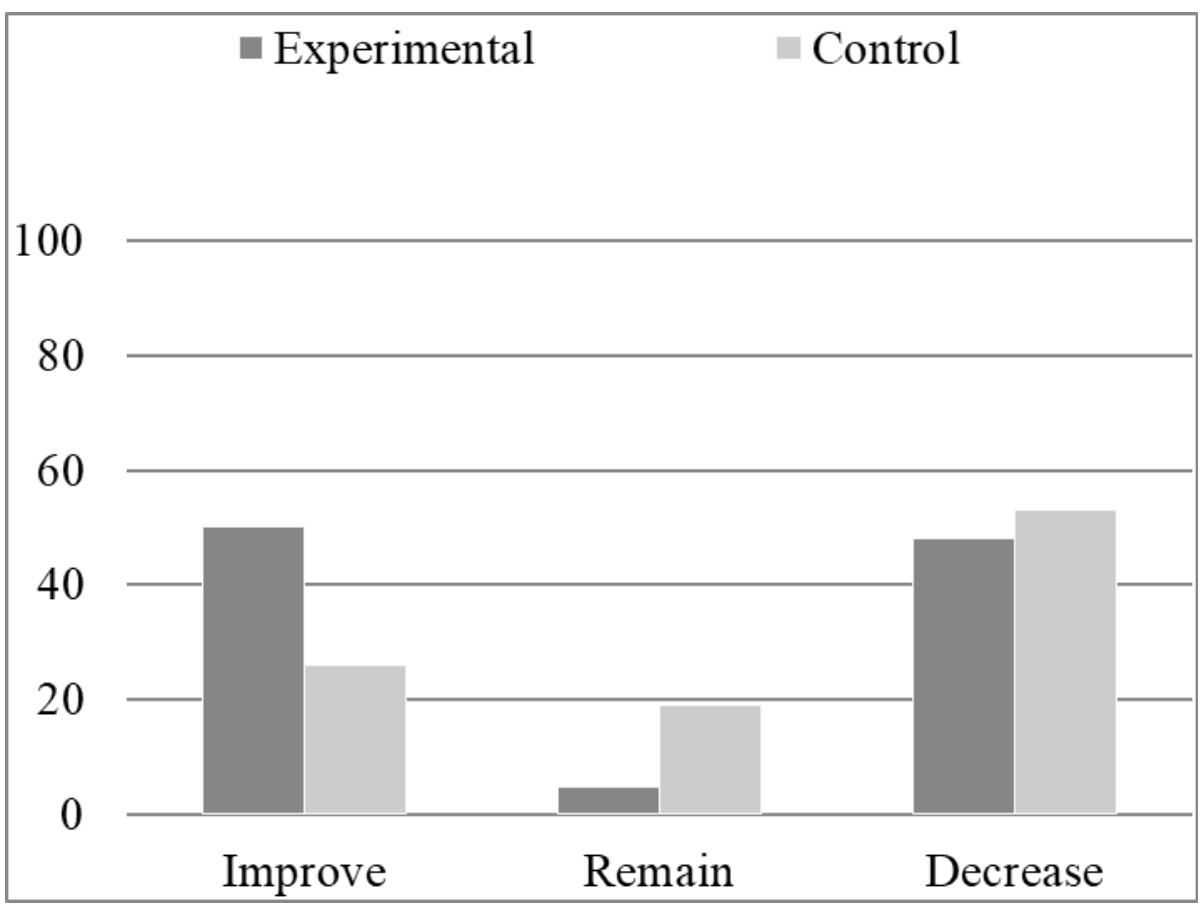

Figure 3. Comparison Between the Two Groups from T1-T2 


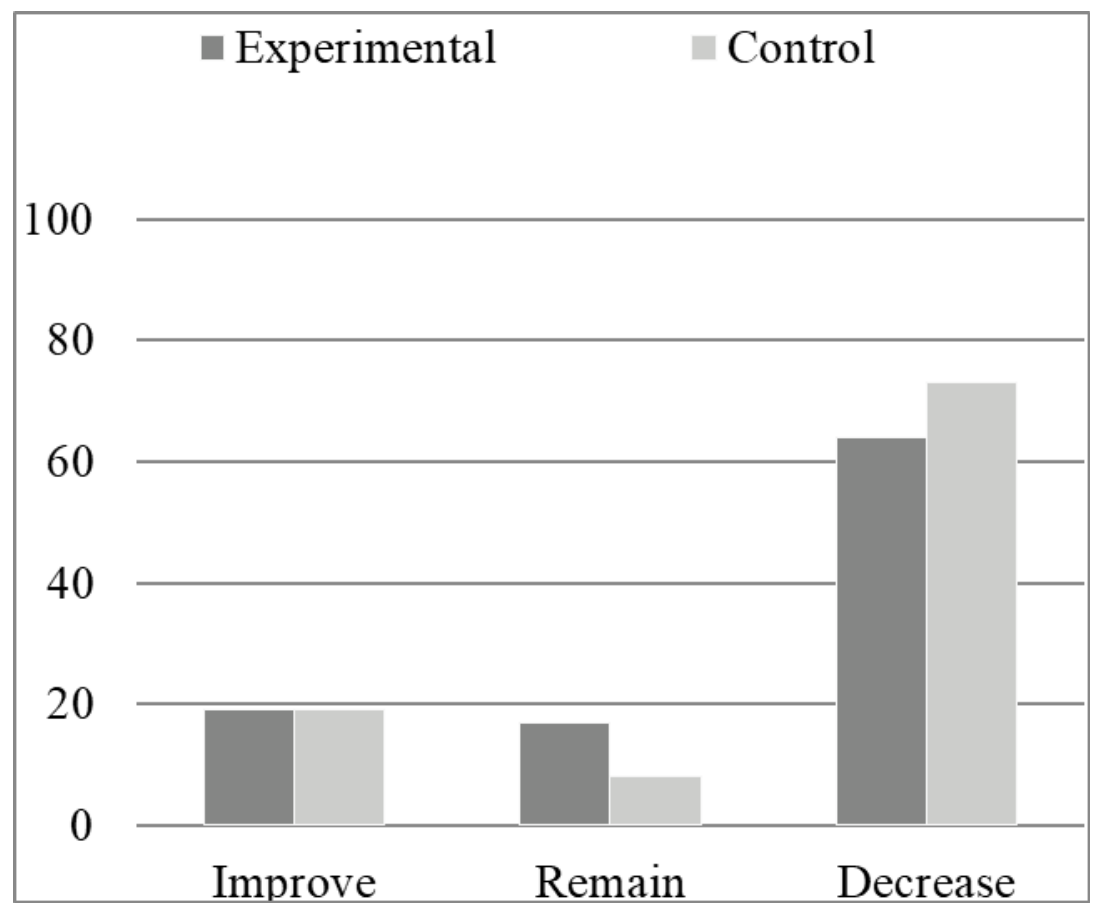

Figure 4. Comparison Between the Two Groups from T2-T3

To sum up, despite the non-significant differences in the results of the VKS tests between the two groups, the changes in the students' performances in the VKS tests still suggest different patterns of vocabulary acquisition and retention resulting from the two approaches. The class journal logs reveal the respective class modes that led to the various characteristics of language learning, which might have been overlooked in the VKS results.

\section{Interactive Inputs and Meaningful Outputs of the Experimental Group}

According to the qualitative data in the teacher/researcher's journal logs, distinctions between the experimental and the control groups were found in regards to class interactions and the language acquisition process. The experimental group was more involved in interactive input and thereby induced a meaningful output. In contrast, the control group was more focused on receiving instruction through a series of procedures that targeted the specific final aims.

In the experimental group, while performing the tasks, the students naturally interacted with the teacher and other classmates, and the students received language input from each other. This was the basis of interactive input. Owing to the characteristics of the interactive input, the students would produce output meaningful to the given context and also to themselves.

\section{Excerpt 1}

T: If I say, "Let's have a test tomorrow!" how do you feel?

S1: No! Teacher!

T: How do you feel?

S2: 緊 張 ["nervous" in Chinese]

S3: 生 氣 [“angry" in Chinese]

Ss: Angry! Angry!

Teacher: Yes, angry. And...?

Ss: Nervous.

Teacher: So, you feel angry or you feel nervous.

For example, Excerpt 1 demonstrates the process of meaning negotiation between the teacher and students in the pre-task cycle (Period 1). Students were already instructed regarding the target words in the aspects of phonology, their basic meanings inferred from pictures, and their spellings. In the beginning, interactive input was demonstrated, as the teacher asked a question about having a test tomorrow. The students' attention was 
drawn to the teacher's question. Thus, an interactive input was created. Some students were startled and some of them shouted out loud. Then, students responded quickly in their first language. The students' responses revealed that they understood the questions and became aware that they could express themselves by using the target words. Next, the teacher drew the students' attention to the meanings and the form of the target words. The dialogue exemplified that students received L2 input through interaction, which had also led to their meaningful output.

As observed in Excerpt 1, the interaction between the students and the teacher seemed to have reached a certain level of language communication and vocabulary acquisition. As the students shifted from their mother tongue to the second language to communicate, the process of mapping between meaning and form is suggested. Students who found the target word might get the gist of applying the word in an appropriate context. Long (1985) points out that interaction provides the linguistic input that occurs during communication and that it can also be seen as a factor in second language acquisition. In addition, many researchers have stated that negotiated interaction can be beneficial for vocabulary learning (de la Fuente, 2002; Mackey, Gass, \& McDonough, 2000; Rees, 1998).

In the next part of Task 1, the students shared their work with others. During the sharing process, more interaction and involvement were induced when they encountered problems. For example, in Excerpt 2, S1 was sharing with S2, but a communicative problem arose due to mispronunciation. S2 helped by telling S1 the correct pronunciation. Another interactive input was found; it was initiated by the student here. The breakdown of the conversation turned the students' attention to the problem, and it was addressed by themselves.

\section{Excerpt 2}

$$
\begin{aligned}
& \text { S1: I feel "ner-ve-s". } \\
& \text { S2: "ner-ve-s"? } \\
& \text { S2: Oh! "Nervous"! } \\
& \text { S1: Ok! I feel nervous. }
\end{aligned}
$$

[Period 2]

In Task 2, the students were asked to write down how they felt in a specific situation. During the task, the teacher noticed some spelling errors and addressed them with the students. Excerpt 3 demonstrates the sharing process in Task 2. It is evident that the students were comprehending the meaning of the sentence as they laughed. Likewise, it raised the students' attention to the target words because the content was interesting to them (they thought that school would be suspended when there was a typhoon). Furthermore, this kind of episode drove the students to attend to others' output more closely. That is, when the content is meaningful to them, it leads to deeper personal involvement and motivation.

\section{Excerpt 3}

S1: I feel mad when there is a test.

S2: I feel glad when there is a typhoon.

[Students laughed]

[During the interview]

S3: I feel worried when there is an earthquake.

S4: What is worried?

S3：擔心 ! [“worried” in Chinese]

S4: Oh!

[Period 3]

That is to say, in the first part of the task, the students had to recognize and understand the meaning of the target words. Second, they had to focus on both meanings and forms in order to produce their output. The students had to go through the two stages, which induced deeper involvement and "pushed" the output during the task. Therefore, the output production gave them a chance to process the input they received or notice the gap while producing.

This corresponds with the studies of Swain (1995), Ellis and He (1999) and de la Fuente (2002). These studies all suggest that output production contributes to acquisition. Furthermore, this current study points out that the language output initiated by students in the experimental group was meaningful and self-directed. Thus, it may 
further deepen their cognitive process that leads to acquisition and enhance their ability to respond to specific contexts.

To conclude the discussion of the findings above, the interactive input involves students with specific types of interactions, such as response, confirmation, and inquiry. This leads to the promotion of the immersion of relatable context and output production. Through the analysis of the class journal logs, it appeared that the students' L2 comprehension was developed through interaction and output production. Nonetheless, the quantitative effects of the focus-on-form TBLT on students' vocabulary acquisition did not reach a significant level. This may be due to the flexible nature of the task, the limited application of target words, and the large class size. Additionally, the instrument (VKS) administered in the study may have been inadequate at differentiating the respective vocabulary learning.

\section{Pre-Modified Inputs and Fixed Outputs of the PPP Model of the Control Group}

The findings show that the PPP lessons provided sufficient practice time for the students to familiarize themselves with and subsume the target words. However, this approach may not cultivate students' L2 comprehension once they are put into a real-life context. In addition, this type of activity could also account for the decreasing change in the retention rates of the words.

The qualitative data showed that the students in the control group acquired a substantial amount of vocabulary, and the students' recognition and memorization of vocabulary were reinforced through these practices.

\section{Excerpt 4}

Activity 3: Guessing game.

S1: Does he feel mad?

T: No, he doesn't.

S2: Does he feel bored?

T: No, he doesn't.

S3: Does he feel upset?

T: Yes, he does!

The practices involved a guessing game, and the students had to guess the chosen classmate's mood. As shown in Excerpt 4, the sentence structure was fixed and lacked a negotiation of meaning, since the interaction was limited to only the teacher and individual students. Sometimes a target word would be repeatedly used because the students were not paying attention to others' output. This might suggest that for students, the meaning and form of the newly learned target words were not embedded within the context. Lessons based on the activity design of the PPP model emphasized intensive rote learning rather than how to use the language. As Willis and Willis (1996) point out, the learners' "production" was still at the practice stage, since the learners were not focusing on the expression of meaning. This was also exemplified in Excerpt 4.

In addition, the PPP model's pre-modified input offered little opportunity for students to notice the barriers between what was learned and what was acquired, and it led to fixed output due to its controlled fashion. This echoes Ellis et al.'s (1994) study in which learners who received pre-modified input received less interaction, which led to a lower level of comprehension.

Based on the findings above, both approaches were effective for the students' L2 vocabulary acquisition at the beginning. The quantitative data showed a relatively high level of L2 acquisition; the mean scores of both groups were all above $27(67.5 \%)$ in the first two tests. Even though both groups dropped in Test 3, they all scored approximately above $22(55 \%)$. Nonetheless, the data also showed that the experimental group demonstrated a lower rate of decreasing scores than the control group did.

In addition, the qualitative data derived from the class journal logs revealed that the students' L2 comprehension could be enhanced through the interaction and negotiation of meaning; this was not reflected in the VKS test results. Also, the activities in the control group may have contributed to a strong and immediate effect on vocabulary acquisition, but they may not sustain the development of L2 vocabulary learning and comprehension due to the lack of an interaction and communicative context.

\section{Conclusion}

The activities in the PPP lessons seemed to contribute to stronger immediate lexical acquisition owing to intensive rote learning, as shown in the results of the VKS tests. This result corroborates the study conducted by 
Laufer (2006); it compared two different conditions, focus-on-form TBLT and a PPP model on vocabulary acquisition and retention. The PPP group scored higher than the focus-on-form group in the immediate test, but the effect disappeared in the delayed test. Our result also echoes Rees's (1998) study in which it was found that learners who received non-interactive learning demonstrated a higher degree of memory loss than those who received interactive learning. Despite its effects on immediate vocabulary acquisition, the vocabulary retention of the PPP group seemed to yield a weaker result compared to the focus-on-form TBLT group. Moreover, it may also be inferred that the activities seldom contribute to L2 comprehension development.

In regard to the lack of an immediate statistical result of the TBLT, this does not only appear in this study (see de la Fuente, 2006). In both de la Fuente's and the current studies, both employed VKS as the quantitative instrument to measure the effectiveness of learning vocabulary after using TBLT, and similar statistical results appeared. A legitimate question might be raised if VKS is suitable to fully measure every aspect of the learners' abilities after instruction with TBLT. In comparing the quantitative and qualitative results of this study, more doubts arise. This might be a potential direction for future research with TBLT.

This study also found that the pre-selected target words from the existing publications may not be easily adapted into a communicative/contextual task design. Thus, the design of the two tasks catered to multiple applications of the target words. This concern is in line with Harris's (2018) finding that there is a lack of existing available materials for application in TBLT classes. This also reflects a drawback of the implementation of TBLT for English teachers. It is suggested that teachers adapt materials and the task design to serve the needs of real-life communication so that the students can carry out the tasks more effectively in the classroom (Ellis, 2003).

\section{References}

Adams, R., \& Newton, J. (2009). TBLT in Asia: Constraints and opportunities. Asian Journal of English Language Teaching, 19(1), 1-17.

Alcón, E. (2007). Incidental focus on form, noticing and vocabulary learning in the EFL classroom. International Journal of English Studies, 7(2), 41-60.

Anderson, J. (2016). Why practice makes perfect sense: The past, present and potential future of the PPP paradigm in language teacher education. Practice, 19, 14-22.

Bygate, M., Skehan, P., \& Swain, M. (Eds.). (2001). Researching pedagogic tasks: Second language learning, teaching, and testing. Longman.

Carless, D. (2004). Issues in teachers' reinterpretation of a task-based innovation in primary schools. TESOL Quarterly, 38(4), 639-662. https://doi.org/10.2307/3588283

Carless, D. (2007). The suitability of task-based approaches for secondary schools: Perspectives from Hong Kong. System, 35(4), 595-608. https://doi.org/10.1016/j.system.2007.09.003

Chen, A. H. (2013). An evaluation on primary English education in Taiwan: From the perspective of language policy. English Language Teaching, 6(10), 158-165. https://doi.org/10.5539/elt.v6n10p158

Chen, H. L. S., \& Huang, H. Y. (2017). Advancing 21st century competencies in Taiwan. Asia Society Center for Global Education. Retrieved from https://asiasociety.org/files/21st-century-competencies-taiwan.pdf

Chern, C. (2002). English language teaching in Taiwan today. Asia Pacific Journal of Education, 22(2), 97-105. https://doi.org/10.1080/0218879020220209

Criado, R. (2013). A critical review of the presentation-practice-production model (PPP) in foreign language teaching. In R. Monroy (Ed.), Homenaje a Francisco Gutiérrez [Homage to Francisco Gutiérrez Díez] (pp. 97-115). Editum, Ediciones de la Universidad de Murcia.

De la Fuente, M. J. (2002). Negotiation and oral acquisition of L2 vocabulary: The roles of input and output in the receptive and productive acquisition of words. Studies in Second Language Acquisition, 24(1), 1-112. https://doi.org/10.1017/S0272263102001043

De la Fuente, M. J. (2006). Classroom L2 vocabulary acquisition: Investigating the role of pedagogical tasks and form-focused instruction. Language Teaching Research, 10(3), 263-295. https://doi.org/10.1191/1362168806lr196oa

Doughty, C., \& Williams, J. (1998). Focus on form in classroom second language acquisition. Cambridge University Press.

Ellis, R. (2001). Introduction: Investigating form-focused instruction. Language Learning, 51, 1-46. https://doi.org/10.1111/j.1467-1770.2001.tb00013.x 
Ellis, R. (2003). Task-based language learning and teaching. Oxford University Press.

Ellis, R. (2009). Task-based language teaching: Sorting out the misunderstandings. International Journal of Applied Linguistics, 19(3), 221-246. https://doi.org/10.1111/j.1473-4192.2009.00231.x

Ellis, R. (2016). Focus on form: A critical review. Language Teaching Research, 20(3), 405-428. https://doi.org/10.1177/1362168816628627

Ellis, R., \& He, X. (1999). The roles of modified input and output in the incidental acquisition of word meanings. Studies in Second Language Acquisition, 21(02), 285-301. https://doi.org/10.1017/S0272263199002077

Ellis, R., Basturkmen, H., \& Loewen, S. (2001). Preemptive focus on form in the ESL classroom. TESOL Quarterly, 35(3), 407-432. https://doi.org/10.2307/3588029

Ellis, R., Tanaka, Y., \& Yamazaki, A. (1994). Classroom interaction, comprehension, and the acquisition of L2 word meanings. Language Learning, 44(3), 449-491. https://doi.org/10.1111/j.1467-1770.1994.tb01114.x

Gass, S. (1997). Input, interaction, and the second language learner. Lawrence Erlbaum.

Gass, S. M., \& Varonis, E. M. (1994). Input, interaction, and second language production. Studies in Second Language Acquisition, 16(3), 283-302. https://doi.org/10.1017/S0272263100013097

Harmer, J. (1998). How to teach English: An introduction to the practice of English language teaching. Longman.

Harris, J. (2018). Responding to the critics: Implementation of TBLT in Japan. Indonesian Journal of Applied Linguistics, 8(1), 139-148. https://doi.org/10.17509/ijal.v8i1.11473

Hutchby, I., \& Wooffitt, R. (2008). Conversation analysis. Polity.

Ji, Y. (2017). Task-based language teaching (TBLT) in Asian EFL classes: Challenges and strategies. In Proceedings of the 2017 World Conference on Management Science and Human Social Development (MSHSD 2017). Atlantis Press. https://doi.org/10.2991/mshsd-17.2018.28

Kit, C. (2003). How does lexical acquisition begin? A cognitive perspective. Cognitive Science, 1(2), 1-50.

Laufer, B. (2006). Comparing focus on form and focus on forms in second-language vocabulary learning. Canadian Modern Language Review, 63(1), 149-166. https://doi.org/10.3138/cmlr.63.1.149

Lewis, M. (1996). Implications of a lexical view of language. In J. Willis \& D. Willis (Eds.), Challenge and change in language teaching. Heinemann.

Lin, T. B., \& Wu, C. W. (2012). Teachers' perceptions of task-based language teaching in English classrooms in Taiwanese junior high schools. TESOL Journal, 3(4), 586-609. https://doi.org/10.1002/tesj.35

Littlewood, W. (2007). Communicative and task-based language teaching in East Asian classrooms. Language Teaching, 40(3), 243. https://doi.org/10.1017/S0261444807004363

Long, M. (2015). Second Language Acquisition and Task-based Language Teaching.

Long, M. H. (1985). A role for instruction in second language acquisition: Task-based language teaching. In K. Hyltenstam \& M. Pienemann (Eds.), Modelling and assessing second language acquisition (pp. 77-99). Multilingual Matters.

Long, M. H. (1998). Focus on form in task-based language teaching. University of Hawai'i Working papers in ESL, 16(2), 35-49. Malden, MA: Wiley Blackwell.

Lyster, R. (1998). Negotiation of form, recasts, and explicit correction in relation to error types and learner repair in immersion classrooms. Language Learning, 48(2), 183-218. https://doi.org/10.1111/1467-9922.00039

Mackey, A. (1999). Input, interaction, and second language development: An empirical study of question formation in ESL. Studies in Second Language Acquisition, 21(4), 557-587. https://doi.org/10.1017/S0272263199004027

Mackey, A., Gass, S., \& McDonough, K. (2000). How do learners perceive interactional feedback? Studies in Second Language Acquisition, 22(4), 471-497. https://doi.org/10.1017/S0272263100004022

Ministry of Education. (2000). INSERT ORIGINAL TITLE [Temporary general guidelines of the nine-year curriculum in 2000]. Retrieved from https://teach.eje.edu.tw/9CC2/9cc_90.php

Ministry of Education. (2014). INSERT ORIGINAL TITLE [General guidelines of the twelve-year curriculum]. Retrieved from https://www.naer.edu.tw/ files/15-1000-7944,c1174-1.php?Lang=zh-tw 
Nunan, D. (2004). Task-based language teaching. Cambridge University Press. https://doi.org/10.1017/CBO9780511667336

Paribakht, T. S., \& Wesche, M. (1997). Vocabulary enhancement activities and reading for meaning in second language vocabulary acquisition. Second language vocabulary acquisition: A rationale for pedagogy, 55(4), 174-200. https://doi.org/10.1017/CBO9781139524643.013

Pica, T. (1992). The textual outcomes of native speaker-nonnative speaker negotiation: What do they reveal about second language learning? In C. Kramsch \& S. McConnell-Ginet (Eds.), Text and context: Cross-disciplinary perspectives on language study (pp. 198-237). D. C. Heath \& Co.

Rees, D. (1998). The negotiation of meaning in EFL learning in the language laboratory. ASP La Revue du GERAS, 19-22, 283-309. https://doi.org/10.4000/asp.2867

Sheen, R. (2003). Focus-on-form: A myth in the making. ELT Journal, 57, 225-233. https://doi.org/10.1093/elt/57.3.225

Shintani, N. (2013). The effect of focus on form and focus on forms instruction on the acquisition of productive knowledge of L2 vocabulary by young beginning-level learners. TESOL Quarterly, 47(1), 36-62. https://doi.org/10.1002/tesq.54

Skehan, P. (1998). A cognitive approach to language learning. Oxford University Press. https://doi.org/10.1177/003368829802900209

Swain, M. (1985). Communicative competence: Some roles of comprehensible input and comprehensible output in its development. In S. M. Gass \& Madden C. D. (Eds.), Input in second language acquisition (pp. 235-253). Newbury House.

Swan, M. (2005). Legislating by hypothesis: The case of task-based instruction. Applied Linguistics, 26, 376-401. https://doi.org/10.1093/applin/ami013

Wesche, M., \& Paribakht, T. S. (1996). Assessing second language vocabulary knowledge: Depth versus breadth. Canadian Modern Language Review, 53(1), 13-40. https://doi.org/10.3138/cmlr.53.1.13

Willis, D., \& Willis, J. (1996). Challenge and change in language teaching. Heinemann.

Yang, C. H., Haggard, S., \& Li, C. L. (2008). The effect of focus on form instruction on Taiwanese EFL college students. Journal of Mei Ho Institute of Technology, 27(2), 125-152. 


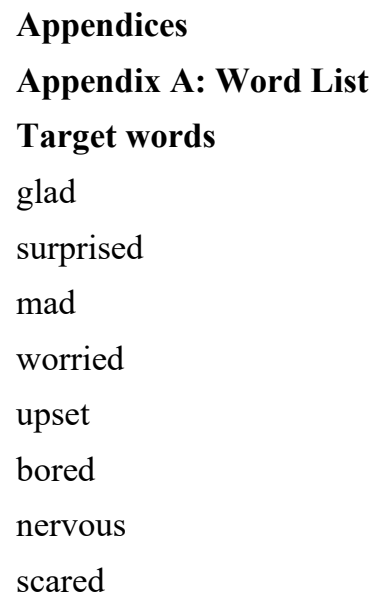

\section{Sentences related to the unit}

How do you feel?

I feel

I don't feel

You look

\section{Appendix B:A Sample of Vocabulary Knowledge Scale (Chinese Version)}

\section{單字量表}

3 年_—班 _ _ _ 號 姓名:

請仔細看過下列的單字, 並『打勾』標示出你對每個單字的認識程度。如果是回答 3 及 4 的部分, 請寫出你 知道的同義字或意思。如果是 5 的部分, 請用那題的的單字造句。注意: 此測驗並不影響成績及學業成就, 學生可依照自己的認知回答即可。

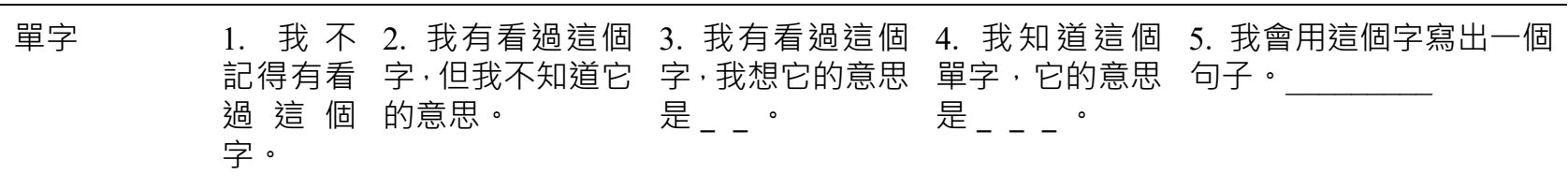

1. lonely

2. surprised

3. upset

4. worried

5. scared

6. nervous

7. bored

8. glad

9. $\mathrm{mad}$

10. feel 


\section{Appendix G: The Chinese Translation List}

The Chinese translations are drawn from the textbook, and some of the Chinese synonyms were mentioned/negotiated during the class.

surprised 驚訝的

upset 苦惱的; 煩惱的

worried 擔心的; 苦惱的

scared 害怕的

nervous 緊張的

bored 感到無聊的; 無聊的

glad 高興的; 開心的

$\operatorname{mad}$ 發狂的; 抓狂的; 生氣的

\section{Copyrights}

Copyright for this article is retained by the author(s), with first publication rights granted to the journal.

This is an open-access article distributed under the terms and conditions of the Creative Commons Attribution license (http://creativecommons.org/licenses/by/4.0/). 